This is an Accepted Manuscript of an article published by Taylor \& Francis in Journal of War and Culture Studies on 07/11/17, available online:

http://www.tandfonline.com/doi/full/10.1080/17526272.2017.1396069 
From War Grave to Peace Garden: Muslim Soldiers, Militarised Multiculture and Cultural Heritage

Professor Vron Ware

Dept of Criminology and Sociology

Kingston University

Penrhyn Rd

Kingston upon Thames

KT1 2EE

02084172717

v.ware@kingston.ac.uk 


\title{
From War Grave to Peace Garden: Muslim Soldiers, Militarized Multiculture and Cultural Heritage
}

\begin{abstract}
The focus of this article is the renovation and rededication of a WW1 cemetery designated for Indian Muslim soldiers, located in Woking, Surrey. The close involvement of the British Army in this project is examined as an instance of militarized multiculture. The centenary of WW1 provides the wider context for exploring the category of 'the Muslim soldier'. The essay discusses the significance of military service for UK postcolonial citizens, whether in terms of advancing claims to belong to British historical narratives or in asserting the right to join the contemporary armed forces, as evidenced by the Armed Forces Muslim Association. In addition, the Islamic peace garden project illustrates the importance of community place-making initiatives for integrating minority cultural heritage into mainstream narratives.
\end{abstract}

Keywords: militarization, war, commemoration, diversity, soldiers, Muslims, colonial history, WW1 centenary 


\section{Introduction}

In November 2015 a former WW1 burial ground for Indian Muslim soldiers who died in England was re-opened as a memorial garden dedicated to peace. Almost a century earlier, the same site in Woking, Surrey, had been chosen as a dedicated cemetery for Indian soldiers who had died after being treated in the temporary military hospitals set up along the south coast. But this was not to be their final resting place. In 1969 the graves by then 27 in number - were relocated to Brookwood Cemetery nearby and the walled grounds returned to the care of the Horsell Common Preservation Society. Today, thanks partly to the efforts of Historic England (HE, formerly part of English Heritage), together with funding from Woking Borough Council and other partners such as the Ministry of Defence (MoD), the Sultanate of Oman and the local mosque, the ruins of the former cemetery were brought back to life as an enclosed garden, reconfigured and planted according to Islamic design principles, and dedicated to the memory of the servicemen once buried there. Throughout this process of renovation, senior officers of the British Army and members of the Armed Forces Muslim Association (AFMA) were active in promoting the project as well as providing practical support.

The various phases of restoration were reported in the local media with staged photographs featuring an array of interested parties, including high-ranking military personnel. In August 2013, for example, the start of the work was marked by a prayer ceremony, led by the Imam Asim Hafiz, formerly Muslim chaplain to the armed forces and now Defence Islamic adviser, and Reverend Ian Brackley, the Suffragan Bishop of Dorking. The occasion was also reported by the Ministry of Defence which published a 
news item on their website. The launch of the second phase in December 2014 also saw a prayer ceremony, led by Imam Dr Syed Naqvi, who represented Woking's Muslim community, and the Assistant Chaplin from the Royal Military Academy in Sandhurst. On this occasion, the event was attended by the Under Secretary of State for Communities and Local Government, Stephen Williams MP, who was reported as saying that the Peace Garden 'will allow this community to reflect on the sacrifice of so many during the First World War and to remember the brave men who came from across the world to fight for our freedom'. ${ }^{1}$ In a separate statement, the Secretary of State for Culture, Sajid Javid, said that the restoration of the Muslim Burial Ground was particularly poignant in the centennial year, adding that the site was 'a symbol of those lost, and an early and important part of British Muslim history'. ${ }^{2}$

This endorsement was evidence that the restoration presented the government with a significant opportunity to assert a meaningful historical connection between those military recruits from undivided India, many of whom had been landless peasants before enlisting, and a new generation of UK-born citizens of Muslim faith and heritage. The message was reinforced by another dignitary at the event, Major General Stuart Skeates, who declared he was proud to represent both the British Army and the Royal Military Academy, Sandhurst. He made a point of claiming that both institutions had connections with the British Muslim community over the course of many years:

The British Muslim community has a great heritage of military service and many have made the ultimate sacrifice to ensure that we can live in peace and prosperity. 
The restoration of this historic site and the creation of a Peace Garden is a wonderful symbol of the bond between the military and Muslim communities and serves as a tribute to those young men and women of all our communities who have gone before us and died in the service of their country. ${ }^{\square 3}$

The strategic value of the collaboration was also highlighted by Historic England (HE), which provided the bulk of the funding for this project. HE made it clear from the start that the site would be a joint initiative with the Ministry of Defence, explaining that it would be 'an integral part of the Armed Forces' ongoing cultural diversity training and annual memorial services for the local community and forces'. ${ }^{4}$ As a way of underlining the value of local military history as a resource for younger generations, students from a local school joined serving soldiers, including members of the Armed Forces Muslim Association (AFMA), and Imam Hashmi from Woking's Shah Jahan Mosque, to plant the $27^{\text {th }}$ and final silver birch tree shortly before the opening ceremony the following year. ${ }^{5}$ The garden, which features a water fountain incorporating a memorial stone inscribed with the names of the Indian soldiers, was then given the royal seal of approval when it was officially opened by the Earl of Wessex on 12 November 2015. Finally, the threeyear process of restoration was captured by a BBC documentary broadcast in January 2016. Aaqil Ahmed, the BBC's head of religion and ethics, reportedly explained that he commissioned the film after seeing the burial ground in its relatively abandoned state and realizing that it was 'a forgotten part of British history and a story worth telling' ${ }^{6}$

It is perhaps inevitable that military service in the cause of defending Britain's interests in 
the past remains an important qualification for enacting modern claims to citizenship and defining the bounds of the political, national and postcolonial community (Paul 1998, Ware 2010). However, in an effort to unpick the different elements involved in the reconstruction of this extraordinary site, it is necessary to focus on the contemporary 'Muslim soldier', a complex figure which has largely escaped the attention of those who study the 'integrated culture of militarism' in the UK (Rogers 2017, p.198). The AFMA, which represents and provides a voice for Muslims inside the institution, has been pivotal in this episode of historic restoration and claim-making. On the one hand, the project has been represented as a largely Muslim-led initiative, demonstrating the agency of the loyal Muslim citizen-soldier who is thoroughly, and historically, integrated into the UK national narrative. On the other, the close involvement of the armed forces in this highprofile renovation project has allowed the institution to showcase the ongoing participation of Muslim personnel serving in the armed forces today (Ware 2013). At a time when Muslim citizens throughout Europe are being stigmatized as disloyal subjects who pose a potential threat to national security (Qureshi and Zeitlyn 2013), the reclamation of the burial ground as a space dedicated to peace demonstrates how the cultural heritage of colonial war can be instrumental in countering anti-Muslim or racist discourse. By asking whose interests are served by the militarization of cultural heritage in Britain, the essay will hopefully contribute to a growing body of critical work on the salience of war, history and memory for the politics of race and citizenship today.

\section{Militarised multiculture}

The restoration of any historic ruin is necessarily a complex task, not unlike the 
painstaking physical labour entailed in archaeological research. There are long lost fragments to be excavated, identified and assessed in the light of present knowledge, and new perspectives on the past to be developed and tested against existing evidence. This site in southern, suburban England is no different. To do justice to its full significance is to bring together many seemingly disparate issues: the centennial commemorations of WW1 taking place on national and local scales; the contested politics of race and colonial war heritage; the hardening of collective identities defined along lines of faith as well as ethnicity and culture; the importance of military labour - and particularly death in service - in grounding minority claims to belong as well as to qualify as loyal citizens; the richness of local histories long buried or suppressed; the contingencies of military recruitment crises; and the wider context of endless war accompanied by the tightening grip of securitization aimed primarily at Muslim communities, not just in British towns and cities but across Europe and the Anglophone world. The thread that I will use to connect these different strands of inquiry is the concept of militarized multiculture, a phenomenon that has helped to reposition the armed forces within civil society within the past decade.

As I have argued in Military Migrants (2012) the concept of militarized multiculture provides a way of encapsulating the connections between the management of diversity within British military institutions and the extraordinary shifts in public attitudes to the UK armed forces that have taken place as a result of wars in Iraq and Afghanistan (Dixon 2012; Gee 2014). The British Army accepted relatively late and rather reluctantly (Frost 2002) that cultural diversity might have value as an institutional tool. The tortuous 
process of reform entailed in reaching this conclusion was to some extent mandated by law, particularly after the Macpherson Report (1999) established the urgency of addressing institutional racism within the public sector ${ }^{7}$. Within scarcely more than a decade, the armed forces reached a position where they could justifiably claim to be a multicultural employer with a workforce - in the army at least - that approximately reflected the level of the Black, Asian and minority ethnic population (BAME) in the UK. ${ }^{8}$ This was achieved partly as a result of the imposition of equality and diversity legislation (Mason and Dandeker 2009; Forster 2012) and the threat of legal action in cases of discrimination, bullying or other forms of harassment (Basham 2009, 2013). The strategy that proved most effective in raising the numbers of BAME recruits was the temporary waiving of the residency requirement for Commonwealth citizens (Ware 2012). ${ }^{9}$ But in addition to the formal recognition of the need to diversify the workforce in terms of colour, ethnicity, gender, sexuality and faith, the institution also discovered, albeit intermittently, that there were advantages in showing a more acceptable face to the public. In short, the visible embrace of diversity was integral to the process of modernization, as a result of which the armed forces could assert themselves as a dynamic and modern employer, equipped to meet the challenges of the 21 st century despite public reservations about the wars that they were engaged in (British Social Attitudes 2012).

There are three reasons why this claim is important to the argument in this essay: first, the representation of the army as a caring and visibly multiethnic employer is a key factor in attempts to attract desperately needed BAME recruits, not least because the proportion of 
minorities within the target age range of $18-25$ is due to rise exponentially. Following the much vaunted restructuring of the armed forces following the 2010 Strategic Defence Review, recruitment figures have been falling ${ }^{10}$ despite new advertising pitches that stress the positive benefits of joining for young people (Farmer 2017). Second, the enthusiastic self-promotion of the AFMA through social media is evidence of an employer that recognises the right of faith groups to represent and develop their distinct identities inside and outside the organisation. The support given by military officials to a communitybased renovation project might therefore indicate that the armed forces have embraced a new-found remit to engage with civil society as a key strategy in developing better links with hard-to-reach communities, such as Muslims. Third, in the context of war heritage and national identity, and specifically the centenary of 1914-1918, the government has been eager to promote the idea that, by bringing together people of diverse cultures, languages and faiths, cultural diversity could be celebrated as a global project with British military origins.

This last point can be illustrated by the launch of an educational initiative to celebrate the 'Commonwealth Contribution' to British victory in WW1. Entitled 'Our Shared Past, Our Common Future,' the project was inaugurated in November 2013 at the offices of the Royal United Services (RUSI) Institute in Whitehall, in the company of a large audience of invited guests, including Imam Asim Hafiz, members of the AFMA including the current Muslim chaplain to the armed forces, and General Sir David Richards, former Chief of the Defence Staff and patron of AFMA from its inception. ${ }^{1}$ The programme was to be delivered by a small organisation called the Curzon Institute which was being 
funded to provide an educational package for schools across the UK. One of its spokesmen was ex-army officer Afzal Amin, a founding member of AFMA who was by then the Tory parliamentary candidate in Dudley. The initiative was endorsed by the prime minister through a pre-recorded video in which David Cameron claimed that British and colonial troops 'fought together ... fell together and together they defended the freedoms that we enjoy today' ${ }^{\square}$ (Commonwealth Contribution 2013).

Baroness Sayeeda Warsi, at that time a member of Cameron's cabinet, chaired the session, expressing unreserved vocal support of the Curzon Institute and their mission to educate. Her welcoming address articulated the mood of the occasion (Warsi 2013):

In his speech 'A Time of Triumph', Winston Churchill praised those who came "from the uttermost ends of the earth" to fight alongside Britain in the Second World War. "From the poorest colony to the most powerful dominion", he said, "the great maxim held: when the King declares war, the Empire is at war".

Warsi declared her own interest in this initiative by adding that both of her grandfathers were 'among those brave men'. But while she had known through her family history that many Indians fought for Britain in WW2, she was unaware of 'the 1,500,000 from modern day India, Pakistan and Bangladesh who served, fought and fell for Britain in the Great War'. This history had been overlooked for far too long, she insisted, 'like a chapter torn from the book of our history' (2013). 
However, this intervention was not simply aimed at replacing the deleted pages; there were also political reasons why the act of restoring this history to young British citizens was so timely. By using the phrase, 'Tommies, Tariqs and Tajinders', Warsi effectively sought to bind the scattered stories of heroism during the course of a brutal global war into an inclusive narrative about contemporary national identity in Britain. The range of different languages and scripts in which the names of the dead were inscribed on gravestones in Belgium and France echoed Cameron's message that diversity was the starkest reminder that 'comradeship, companionship and co-existence cut cross all faiths'. Through the recognition that these stories of heroism were multi-ethnic and multi-faith, she argued, the descendants of those soldiers would be able to 'reclaim our proud, patriotic history', proving that 'this wasn't the all-white war' that many believed it was. By silencing their critics, they would also be able to "wrestle the Union Jack from the hands of the far right', including 'the ignorant people like Anjem Choudary and his followers' (Warsi 2013).

Warsi's evocation of Choudary ${ }^{11}$ illustrated how the government's security agenda was able to endorse diversity not just as a public good but also as an antidote to radicalisation. The coalition government, led by a Tory prime minister, was acknowledged to be the driver of this initiative to educate a new generation of young British citizens about their rightful claims to a military heritage that had been denied to them, not by the willful neglect of this topic in the national curriculum, but by the actions of 'the far right'. Particularly striking was the forthright language used to praise the virtues of multi-ethnic, multi-faith cohesiveness made possible in war, an emphasis that felt at odds with 
Cameron's previous pronouncements on the failures of multiculturalism in Britain (Klug 2015).

In his carefully tailored speech screened at the start of the launch event, Cameron invited his audience to view the centenary of the 1914-1918 war as a chance to 'come together to understand, not the only the scale of the sacrifice, but also the individual stories behind the statistics...stories that show you the strength of the bond between soldiers of all faiths, colours and races' (Commonwealth Contribution 2013). This emphasis gave added weight to the domestic mission to persuade the British-born descendants of those soldiers that military service belonged to an honourable family tradition and was part of their blood heritage, regardless of faith or ethnic origin. It was also intended to boost Britain's status as a global power by reminding Commonwealth countries that their experience of fighting in the British Expeditionary Force in WW1 was proof of shared suffering and sacrifice in a very different world (Ware 2014, p. xxx; British Future 2012). Thus the familiar message that the carnage of $20^{\text {th }}$ century warfare could be recuperated as a fundamentally noble endeavor was repeated through many channels, from the politics of identity at home to the practice of cultural diplomacy on an international level. However, it would be a mistake to see the launch of the Curzon Institute's educational programme outside the context of the wider centennial commemorations.

In 2012, Cameron announced a substantial programme of events and initiatives to be funded by money from the Treasury and partners such as the Heritage Lottery Fund. These included a $£ 35 \mathrm{~m}$ refurbishment of the WWI galleries at the Imperial War Museum 
to be funded through the Libor fines; a series of national, high profile commemorative events marking the anniversaries of significant phases of the war, such as the Battle of the Somme in July 1916; a commitment of $£ 5.3$ million, jointly funded by the Department for Education and the Department for Communities and Local Government, to support pupils and teachers in English secondary schools to visit WW1 battlefields and take part in remembrance ceremonies in northern Europe; and at least $£ 15 \mathrm{~m}$ from the Heritage Lottery Fund, including a new $£ 6 \mathrm{~m}$ fund for community projects (Gov.uk 2012). There is no doubt that this last measure has encouraged several important projects that highlight the extent of colonial labour deployed in the course of the war, a topic that has long been played down in mainstream narratives of British military prowess (Siblon 2012). Before addressing the restoration of the Muslim Burial Ground Peace Garden in more detail, it is first necessary to look more closely at the contested politics of race and colonial war heritage which provides the context in which this particular heritage site has acquired such significance.

\section{Theatrics of blood}

This essay seeks to question the association between military service and as the cornerstone of citizenship and belonging in the $21^{\text {st }}$ century. On the face of it, the restoration of the former graveyard is a prime example of a locally-based commemorative project that offers a stigmatized community the chance to feel included in the national effort to mark the centenary (see, for example, Lockley 2016). US anthropologist John Kelly wrote that 'Stories of blood sacrifices for the nation can irrigate, ennoble and even sanctify the projects of many interested claimants' $(1995$, p. 495). In his analysis of what 
he calls the 'theatrics of blood' in a different geographical and historical context, he suggested that "Arguments about shed blood can be powerful tools for social movements out to make or unmake political limits' (ibid). Military history - whether deeds of past glory or simply the re-iteration that 'We Were There Too' - acquires value as a resource for survivors and descendants, whether it is made to re-articulate group identities or provide the basis of assimilation and integration strategies (Krebs 2004). In the UK and elsewhere in Europe, a combination of factors has re-animated discussions about the significance of military service - and specifically death in uniform - for grounding citizenship claims for postcolonial migrants and their descendants (Qureshi 2013, Ware 2010). Yet as Nirmal Puwar writes in an essay on the 'Spatial Interruptions of War, Nation, and Memory', while these kinds of gestures aspire to bring in those who have been hitherto excluded, 'they are largely limited by the fact that the categories that pervade our existing notions of the nation and the national archives remain largely unquestioned' (2011, pp. 329-330). She cautions that despite the widening of 'the national story' entailed in these kinds of projects, 'what continues... in our post-colonial times, is the performative centering of the national memory of war in royalist and militaristic forms of nationalism.' (ibid).

Using the Peace Garden as a barometer, this essay argues that it is important to challenge the dominant patriotic script, not least because it effectively obscures the details of European colonial rule that have shaped so much of contemporary social and geopolitical identities. Researching the background to the burial ground not only entails an investigation into the wider posthumous meanings attached to the deaths of black, Asian, 
African, Chinese and ethnically marked groups while wearing British military uniform, whether they were buried with appropriate funeral rites or not, in the course of fighting for Britain. The decision to locate the burial ground in Woking also provides an opportunity to bring to public attention a relatively unknown chapter of the development of Islamic practices and institutions in Britain. In turn, this can provide a more complex geopolitical account of the role of Islam in European imperialist calculations, including the exploitation (by European powers) of Islamic concepts such as Jihad. In this instance, the burial ground was created as a direct consequence of German attempts to persuade Muslims throughout the British Empire to switch allegiance to the Ottoman caliphate. Historian David Olusoga (2014) has described the 'choreography' of the fatwa issued by the ruler of Ottoman Turkey in November 1914, which was 'intended to legitimize the Jihad according to Koranic scripture' (213). The fourth and final fatwa leading to the declaration of 'holy war' was directly addressed to Muslim soldiers who were fighting for the Allies.

These soldiers 'who in the present war are under England, France, Russia, Montenegro and those who give aid to these countries by waging war against Germany and Austria, allies of Turkey, do they deserve to be punished by the wrath of God as being the cause of harm and damage to the Caliphate and to Islam?' The answer is 'Yes' (ibid).

These details can be used productively to uncover and celebrate a richer, more nuanced history of Muslim life in Britain in the late $19^{\text {th }}$ and early $20^{\text {th }}$ century. Much of that 
information, however, is readily available to whose who know where to look for it. In addition to the fictional account of the journey that hundreds of Indian sepoys made to the trenches in northern France, which is represented in riveting detail in Mulk Raj Anand's novel Across the Black Waters (1939), the history of South Asian military labour employed in the British Expeditionary Force in Europe relies largely on the foundational work of scholars such as David Omissi (1998, 1999, 2007), Humayun Ansari (2004, 2007) and Santanu Das (2013). But rather than focus on the experiences of Indian soldiers engaged in the process of combat, the restoration of the former graveyard demands an explanation of how a small proportion ended their lives in southern England and why their interment caused such controversy.

\section{A Sense of injustice}

In a fascinating article on Indian encounters with Europe, Omissi (2007) emphasises that many Indian soldiers came to Britain as a result of the outbreak of war in Europe in 1914. Drawing on the letters written by the soldiers to their families back in India, he pays particular attention to the faith-based rituals and restrictions that were a reminder of the expertise gained by British colonial authorities following the 1857 National Uprising. He notes, for example, that,

The authorities took particular care over religious provision in the various hospitals and convalescent homes, not least because they did not want letters home to cause religious anxiety in India. The Pavilion hospital had separate kitchens for Muslims, meat-eating Hindus and vegetarians; and both pork and beef were banned from the 
premises (378).

Despite this degree of sensitivity which replicated customs in the British Indian Army itself, anxieties about disrupting the racial order of the time meant that the Indian soldiers were separated from their white counterparts, kept them away from female nurses and banned, on pain of flogging, from strolling outside the grounds of their convalescence homes without an escort. As Omissi explains:

The soldiers wrote about their situation, apparently without fear of the censorship, and several men compared their condition to being in 'prison'. One Indian subassistant surgeon took matters into his own hands and, as a protest, tried (and failed) to shoot the hospital commandant, Colonel Bruce Seton. For this act, he was sentenced to seven years' rigorous imprisonment. Eventually, the rules about mixing with British civilians were relaxed, because of the resentment that they had caused, and those men well enough to do so were allowed to stroll about the town in pairs, for two and a half hours at a time, accompanied by a British soldier (380).

The letters provide evidence that many were depressed: 'A sense of injustice also informed the feeling, occasionally expressed after the Indians suffered heavy losses at the Second Battle of Ypres, that the sepoys were being sacrificed to spare the lives of British troops' (381). However, despite the hundreds slaughtered in Europe, there seem to have been relatively few deaths among those who were given medical treatment in England. Those who died were accorded appropriate funeral and burial rites. Between 1914-1918, 
53 Hindus and Sikhs were cremated on a specially built funeral ghat on the South Downs, overlooking Brighton, and their ashes scattered in the sea. A chattri was built to commemorate the site. The first Indian soldier to die in England was Ahmed Khan, a Muslim who was buried in the Mohammedan Cemetery adjacent to the village of Brookwood, near Woking, in December 1914.

The distinctive heathland found in that part of southern England was allocated for common use after being protected from enclosure since 1805 . Recently designated as a Site of Special Scientific Interest (SSSI) because of its birdlife, the area, now called Horsell Common, bears testimony to the historical presence of Muslims in British social and cultural life, regardless of any military connection. The cemetery at Brookwood was known for its 'ethnically and religiously pluralistic character', partly because it contained the oldest Muslim burial ground in the country, dating back to the late nineteenth century (Ansari 2007, p. 559). In 1889 ex-colonial official called G. W. Leitner, who was previously the Registrar at the University of Punjab in Lahore, raised sufficient funds among Indian Muslims to establish an Oriental Institute in Woking which he intended to be a centre in Europe for the study of 'Oriental languages, culture and history' (Haq 1930). He was also responsible for building a purpose-built mosque adjoining the centre, the first to be built in the UK. In 1913, by which time the mosque had fallen into disrepair, Khwaja Kamal-ud-Din, a lawyer who had traveled to Britain after pleading a court case with the Privy Council, and who was a dedicated member of the Ahmadiyya Movement ${ }^{12}$, launched the Woking Mission 'with the object of presenting the true picture of Islam and refuting the highly distorted image of Islam that was widely-prevalent in the 
West at the time' (Haq 1930). Meanwhile the plot in Brookwood cemetery which was originally allocated for use by members of this growing Muslim community, had grown into a recognised burial place which further marked this Surrey town as a centre for British and visiting Muslims (Ansari 2007, p, 559).

The Woking Herald ran a report of Khan's funeral which illustrates the role that local Muslims, led by Khwaja Kamal-ud-Din and others, played in mediating the details of custom and deference:

The first burial in this country of an Indian soldier who has died as a result of wounds received while serving with the Indian Expeditionary Force at the front took place in the Mohammedan Cemetery at Brookwood on Monday afternoon. He was Ahmad Khan, of the 3rd Sappers \& Miners, and he died on board a transport while on the way from France to Netley Hospital, on November 4. On Saturday the body was conveyed to the Woking Mosque in a motor hearse, the coffin being enshrouded in a Union Jack. The community of Muslims at the Mosque made arrangements with the Necropolis Company for the interment, which was not largely attended, chiefly on account of the fact not being generally known, but most of the Mohammedans at Woking were present, amongst them being an Arab from Medina, the burial place of the Prophet Mahomet.

The report went on to describe how the burial was conducted according to appropriate ritual. Writing about the way in which burial has contributed to the establishment of a 
Muslim presence in Britain over the past 200 years, historian Humayun Ansari cites a description of the burial of another Indian Muslim officer in 1915, taken from the Islamic Review (2007, p. 558):

At the request of the imam of the Woking mosque, the local commanding officer detailed fifty soldiers, headed by an officer, to attend the funeral in order to pay military honours to this gallant soldier. Three rounds were discharged and, in a fusion of Muslim practices with British military traditions, the 'Last Post' was sounded by the bugle boys'.

Despite this due attention to military protocol and the apparently diligent attention given to Moslem burial customs in Brookwood, the War Office became concerned about the possible impact of German propaganda. A report in the Woking Herald once again summed up the situation:

...very grievous lies and false reports were being spread by the Germans amongst the Indian troops as to the manner in which we were dealing with the Mohammedan wounded and dead; it was of the utmost importance that the conscientious scruples of Indian troops should be carefully observed and every consideration given to them (Ansari 2007, p. 560).

The British were aware of the fact that the Germans were distributing leaflets in the trenches, specifically aimed at Indian soldiers. These materials gave details of the fatwa 
issued by the Ottoman Caliphate, urging Muslims that it was their sacred duty to change sides, an episode described in some detail in Anand's novel (1939/2013). The charge that the British government was not burying Muslim soldiers with due respect was a powerful incentive for mutiny, as the War Office was well aware (Omissi 1998). In order to counter these allegations, it was therefore decided to commission a new burial ground specifically reserved for Muslim soldiers. An area was chosen near the Woking mosque along the bank of a canal on Horsell Common, some 500 yards away (Aziz 2014). Ansari writes that the chairman of the local urban council welcomed the Muslim cemetery, describing it as 'an honour to have men who fell as a result of the war buried in the district' (2007, p. 561). An India Office surveyor and architect, T. H. Winney, designed the enclosure so that its arches, minarets and domed gateway reflected the traditional Indo-Arab architectural style of the Woking mosque, and the structure was built by a local firm. The burial ground was completed in 1917 and subsequently received the bodies of 19 Indian soldiers from the British Expeditionary Force who died between 1914-1918.

Despite this dense chapter of social history merely sketched out here, the fate of the military cemetery in Woking was to be determined by lack of funds as much as by lack of interest. Initially, the newly formed Imperial War Graves Commission (IWGC) took responsibility for the maintenance of the cemetery in 1921 and by 1945 there was a total of 27 gravestones as eight more were added. The site then fell into disrepair, possibly due to the organisation's policy of differentiating between the treatment of 'white graves' and those of 'natives' (Barrett 2007). In 1969 the graves were removed and the renamed Commonwealth War Graves Commission (CWGC) transferred the bodies to Brookwood 
Cemetery which, as Ansari notes, 'has continued to contribute, through the expression of the funerary rituals carried out there, to the construction of Muslim collective memory in a culturally pluralizing Britain' (2007, p. 562). At this point, the ownership of the site reverted to the original landowner, the Horsell Common Preservation Society. Photos taken in the intervening period show the walls and gateway reclaimed by the ecology of the common, despite various attempts to raise money for their upkeep. In 1984, Historic England (HE) awarded the structure a Grade 2 listing due to its 'unique and special interest in a national context'. The original entry noted its historical significance as a rare purpose-built structure for the Muslim community. Horsell Common Preservation Society was unable to raise funds to restore the site, even though HE carried out a review in 2010 when they reaffirmed the architectural and cultural importance of the building. However, it was not until the prospect of the centenary of WW1 loomed on the horizon that HE had a change of heart. At this point they offered to fund $80 \%$ of the cost of repairs to the structure, and the Department for Communities and Local Government provided $£ 50,000$ funding to Woking Borough Council to make up most of the remainder. - Support was also provided by the Armed Forces Community Covenant Grants Scheme, Government of the Sultanate of Oman, Shah Jahan Mosque and Surrey County Council Community Improvements Fund. Where the militarization of multiculture, outlined earlier, helps to explain why this site acquired such value, it would be a mistake to overlook the role played by Muslims within the armed forces themselves. Here we examine the role of AFMA in mediating the ongoing crisis in military recruitment in the wider context of a counter-terrorism agenda aimed primarily at Muslim communities. 


\section{The British Muslim soldier}

It may seem obvious to restate the fact that war routinely fixes and reifies ethnic and national identities, or as historian Tarak Barkawi puts it, "war and representations of sacrifice in war are engines of reification' $(2004$, p. 161). Whereas Barkawi was referring specifically to identities formed in the course of war fighting, militarized multiculture can also make ethnicity and religion meaningful in other military settings. The Armed Forces Muslim Association (AFMA) was founded in the context of the war in Afghanistan (Ware 2013, pp. 132-5) and re-launched in the course of the garden's restoration with an enhanced public profile. In 2015 the group won the Employee Network Public Sector Award 'for the organisation with the best race or cultural diversity employee network group' (MoD 2015). Its founding member and most energetic proponent, Imam Asim Hafiz, has provided a voice within the institution that is able to vocalize the needs and concern of some 400-500 Muslim personnel (Sengupta 2015) while at the same time advocating for the rights of UK-born Muslims to join the armed forces without prejudice (see, for example, the BBC Radio 4 documentary Salam to Queen and Country March 2017). The AFMA twitter profile states that the organization supports their members to 'perform their military duties in full without compromising their faith,' and is regularly updated as a recruitment tool aimed at young Muslims. The account repeatedly emphasizes that there are five MoD policies devised specifically to support Muslims, such as allowances for prayer time, halal food and performing the Hajj. It frequently mentions LCpl Jabron Hashmi, who died in action in Afghanistan in 2006, and whose memory was honoured at a special Iftar held at the defence headquarters in June 2016 to 'recognise 100 years of Muslim service'. Significantly, out of 375 tweets over a six 
months period from October 2016 to April 2017, I noted that 23 per cent showcased Muslim soldiers, female and male, who were commemorated for their heroism in WW1 and WW2. These tweets included many references to the renovation of the Muslim Burial Ground Peace Garden in Woking. As we have noted, Imam Asim was a prominent figure in all the ceremonies throughout the process as his institutional status made him wellplaced to negotiate between various government departments, military officials and members of local organisations who were publicly committed to the restoration. Although not a soldier himself, he has been notable for his insistence that Muslims are entitled to serve their country, defying the assumption that there is no place for Muslims in the British military.

In addition to signalling AFMA's intervention as a voice articulating a British Muslim military perspective, it is also necessary to look at the armed forces' recruitment strategies. The 2010 defence review entailed an ambitious structuring of British Army over the next decade, beginning with a reduction in size from 102,000 to 82,000 regular soldiers and an increase in the number of reservists from 19,000 to 30,000. In another major change, recruitment was outsourced to Capita in March 2013. In July 2016, however, there were just 79,590 trained regular soldiers; the RAF and the navy were also reported to be short of their fully-trained strength as well. These figures were blamed on 'low unemployment, a lack of operations and stubbornly low morale after years of cutbacks' (Farmer 2016). Behind this story of fluctuating recruitment, however, there is a longer narrative of the institution's failure to attract minority ethnic applicants (Mason \& Dandeker 2009). The impact of equality and diversity legislation since 2000, and the 
pressure to recruit from BAME communities, has meant that the army, in particular, has been obliged to use outreach strategies which speak directly in terms of culture, faith and identity; young people are routinely approached through categories such as Muslim, Hindu or Sikh, mediated by gatekeepers in mosques, madrassas, temples and gurdwaras (Ware 2012). The AFMA twitter account indicates that there has been some success in building conversations in cities such as Bolton, Birmingham and Leicester, for example, with illustrations of seminars, visits and exercises taking place on Islamic premises. While there are no figures to indicate whether these dialogues have provided effective in increasing recruitment, the proof that they are taking place demonstrates that the security services are able to embrace the rubric of equality and diversity for their own strategic purposes. This comes across in media reports of these initiatives as being intrinsic to the counter-terrorism agenda.

In early 2015, for example, the head of the Army, General Sir Nick Carter, announced a recruitment drive to attract more BAME candidates. He publicly stated: 'Our recruitment from Black, Asian and Minority Ethnic Communities have been improving over the years, but it is nowhere near it needs to be, we have to do more' (Sengupta 2015). Insisting that the organization was mostly concerned with the quality of the individual recruit, he reiterated the standard line that 'The values and standards we espouse resonate closely with these communities and there is much common ground that we can build on to broaden our recruitment base' (ibid). Despite the fact that the official press release did not mention any particular minority, the media instantly amplified the message with headlines claiming that the British Army was launching a drive to recruit more Muslims. 
The report in the Independent spelled it out: 'The British Army is making a determined push to recruit Muslims in an attempt to counter the rise in radicalisation which has seen hundreds of young men from this country join violent extremist groups like Isis and alShabaab' (Sengupta 2015). The Guardian reported that the army had been trying to engage with communities in places such as Bradford and Burnley, 'where Muslims account for about $25 \%$ and $10 \%$ of the population respectively' (MacAskill 2015) and that further recruiting drives were planned in those towns. The Mail reiterated the stock line that there were more Muslims leaving the country than there were in the forces: ‘Army drive for more Muslims after Paris massacre and rise of Islamic State as it's revealed just 480 are currently serving' (Brown 2015). However, despite this lurid headline, the Mail also provided an indication that the recruitment drive was not all about numbers. Citing the MoD's press release, the journalist included the statement that 'diversity in all its forms drives change and can be a key factor in organisational agility. This agility is key for an Army facing evolving and hybrid threats' (Brown 2015). While this formulaic reference does not name the cultural attributes that are so valuable, it provides further evidence of the strategic value of diversity in a heavily militarised setting. It is worth noting, however, that no such claim about agility and the merits of diversity were made when a number of white servicemen were arrested for belonging to a banned neo-Nazi organization (Davey 2017; see also fn9).

\section{Conclusion}

This point returns us to the Muslim Burial Ground Peace Garden and its significance in promoting the type of counter-terrorist, counter-extremist message endorsed by Baroness 
Warsi in 2013. In May 2016 the UK Defence Academy hosted a conference of International Military Religious Leaders. Delegates included Imams, chaplains and representatives from 16 countries, including, among others, Jordan, Bahrain, Saudi Arabia, Egypt, Pakistan, Malaysia, Brunei, Kenya and Bosnia, UK and Canada, who were invited to attend a commemorative event in the garden. Images were dutifully recorded on the AFMA twitter account, with text explaining that the conference was held to 'foster dialogue to tackle extremism around the world'. One participant was photographed against the backdrop of the gathering, with the words: 'I didn't think I would find such a place that shows the respect that Britain has for Muslims'. This note of appreciation, tinged with disbelief, can be used to draw together the themes of this essay.

The restored memorial garden has furnished the British Army with a rich opportunity to acknowledge the contribution that Muslim soldiers have made throughout its military history. In doing so, it has created a resource that can be used to exploit those historical connections in ways that meet the demands of defence and security policy, from demonstrating a commitment to diversity inside the organization to conducting public diplomacy on a global scale. The enthusiastic participation of Muslim service personnel in the restoration project demonstrates that this is a strategy open to UK Muslims as well. In doing so, it offers proof that, in the current security climate, military service remains, for some, a viable footing for asserting claims to citizenship today, especially when embedded in a longer history, not just of colonial war but also the establishment of Muslim communities in the UK. However, despite the proliferation of centenary-based projects demonstrating the extensive participation of colonial troops in WW1, it remains 
deeply problematic that minority groups, especially those of Muslim faith, should have to 'prove' their right to belong by showing their readiness to die for their country. This essay has argued that the extraordinary story of the Woking site and its recent renovation can be made to reveal hidden facets of today's militarized multiculture, while also offering suppressed historical evidence about the conditions under which Indian soldiers served in Britain's colonial army, at what cost and with what consequences. Thus it can potentially create fresh opportunities to challenge dominant histories of empire and complacent accounts of its legacy today, thereby educating younger generations about the cultural heritage of war and contesting the role of military work as the touchstone for contemporary forms of belonging.

\section{References}

Anand, M. R.,1940/2008. Across the Black Waters. New Delhi: Orient Paperbacks. Ansari, H., 2004. The infidel within: Muslims in Britain since 1800. London: C. Hurst. Ansari, H., 2007. "'Burying the dead": making Muslim space in Britain', Historical Research, vol. 80, no. 210, 545-566.

Aziz, Z., 2014. 'Burial of Indian Muslim soldiers of World War 1 in England — How it began in November 1914'. Middlesex: Ahmadiyya Anjuman Isha'at Islam Lahore (U.K.) Barrett, M., 2007. 'Subalterns at war: First World War colonial forces and the politics of the Imperial War Graves Commission'. Interventions. 9:3, 451-474.

Barkawi, T., 2004. Peoples, Homelands, and Wars? Ethnicity, the Military, and Battle among British Imperial Forces in the War against Japan. Comparative Studies in Society and History, Vol.46 (1), 134-163. 
Basham, V., 2009. 'Effecting Discrimination: Operational Effectiveness and Harassment in the British Armed Forces,' Armed Forces \& Society, vol. 35, no. 4, 728-44.

Basham, V., 2013. War, Identity and the Liberal State: Everyday Experiences of the Geopolitical in the Armed Forces, Abingdon: Routledge.

British Future, 2012. "Lack of knowledge of Indian soldiers in WWI must change".

Posted on 4 November. http://goo.gl/4NSxQy (accessed 02.03.17)

British Social Attitudes, 2012. 'The UK's Armed Forces: public support for the troops but not their missions?' NatCen Social Research, $29^{\text {th }}$ Edition.

http://www.bsa.natcen.ac.uk/latest-report/british-social-attitudes-29/armedforces/introduction.aspx (accessed 01.05.17)

Brown, L., 2015. 'Army drive for more Muslims after Paris massacre and rise of Islamic State as it's revealed just 480 are currently serving'. MailOnline. 6 February. http://www.dailymail.co.uk/news/article-2942060/Army-drive-Muslims-Paris-massacre-

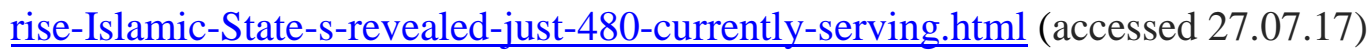
Commonwealth Contribution. 2013. For the complete speech, see the website 'Welcome to the First World War, The Commonwealth Contribution'. http://goo.gl/3TtTxX (accessed 24.04.14).

Das, S., 2013. ed. Race, Empire and First World War writing, New York, NY: Cambridge University Press.

Davey, J. 2017. 'We must act fast to stop far-right groups targeting military personnel'. Guardian. Wednesday 6 September.

Dixon, P., ed. 2012.The British Approach to Counterinsurgency. Basingstoke: Palgrave Macmillan. 
Farmer, B., 2017. 'Army fights troops shortfall with new recruitment ads about camaraderie'. The Telegraph, 6 January.

http://www.telegraph.co.uk/news/2017/01/06/army-fights-troops-shortfall-newrecruitment-ads-camaraderie/ (accessed 02.03.17)

Farmer, B., 2016. 'Army shrinks below 80,000 as recruitment struggles'. The Telegraph, 2 September. http://www.telegraph.co.uk/news/2016/09/02/army-shrinks-below-80000as-recruitment-struggles/ (accessed O2.03.17)

Forster, A., 2012. 'British Judicial Engagement and the Juridification of the Armed Forces,' International Affairs, vol. 88, no. 2, 283-300.

Frost, G., 2002. 'How to Destroy an Army: The Cultural Subversion of Britain's Armed Forces,' in Alexandrou, A., Bartle, R. and Holmes. R. (eds.) New People Strategies for the British Armed Forces, London: Frank Cass, 37-48.

Gee, D., 2015. Spectacle, Reality, Resistance: Confronting a Culture of Militarism. London: ForcesWatch.

Gov.uk, 2012. Prime Minister announces Government plans to mark centenary of First World War in 2014. 11 October. https://www.gov.uk/government/news/prime-ministerannounces-government-plans-to-mark-centenary-of-first-world-war-in-2014 (accessed 27.04.17)

Haq, K.A., 1930. 'The Mosque at Woking: A miniature of Mecca in the days of the Pilgrimage'. The Islamic Review, July 1930, pages 242-244. (http://www.wokingmuslim.org/history/kh-mosque.htm (accessed 01.06.16) Kelly, J. D, 1995. 'Diaspora and World War: Diaspora and Nation in Fiji and Hawai'i. Public Culture, 7: 475-497. 
Klug, B., 2015. 'Fawlty Logic: The Cracks in Cameron's 2011 Munich Speech'. ReOrient. Vol. 1, No. 1 (Autumn), 61-77.

Krebs, R. R., 2004. 'A School for the Nation? How Military Service Does Not Build Nations, and How It Might.' International Security, vol. 28, no. 4, 85-124.

Lockley, M., 2016. The 'forgotten' army of 400,000 Muslim soldiers who fought in Great War trenches for Britain. Birmingham Mail. November 13.

http://www.birminghammail.co.uk/news/midlands-news/forgotten-army-400000-muslim-

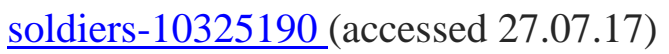

MacAskill, E., 2015. 'British army aims to recruit more Muslims after worries over low numbers'. Guardian. 6 February. https://www.theguardian.com/uknews/2015/feb/06/british-army-recruit-muslims-low-number-iraq-afghanistan (accessed 27.07.17)

Macpherson Report. 1999. The Stephen Lawrence Inquiry. Report of an Inquiry by Sir William Macpherson of Cluny. (Cm 4262-I. February).

Ministry of Defence. 2015. Armed Forces' double win at UK Race Equality Awards. Gov.uk. 7 October. https://www.gov.uk/government/news/armed-forces-double-win-at-

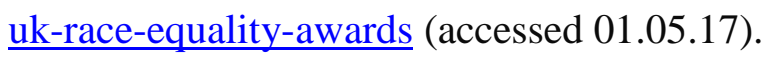

Olusoga, D., 2014. The World's War. London: Head of Zeus.

Omissi, D., 1998 The Sepoy and the Raj: The Indian Army, 1860-1940: Politics of the Indian Army 1860-1940 (Studies in Military and Strategic History), Basingstoke:

Palgrave Macmillan.

Omissi, D., 1999 Indian Voices of the Great War: Soldiers' Letters, 1914-1918. Basingstoke: Palgrave Macmillan. 
Omissi, D., 2007 ‘Europe Through Indian Eyes: Indian Soldiers Encounter England and France, 1914-1918’ English Historical Review Vol. CXXII No. 496, 371-396.

Mason, D. and Dandeker, C., 2009 'Evolving UK Policy on Diversity in the Armed Services: Multiculturalism and its Discontents', Commonwealth \& Comparative Politics, 47(4), 393-410.

Paul, K., 1997. Whitewashing Britain: Race and citizenship in the postwar era. Ithaca: Cornell University.

Puwar, N., 2011. 'Noise of the Past'. The Senses and Society, 6:3, 325-345.

Qureshi, K., 2013. 'Diasporic citizenship and militarization: Punjabi soldiers in the world wars'. Citizenship Studies, Vol. 17, Nos. 3-4, 400-413.

Qureshi, K. and Zeitlyn, B., 2013 'British Muslims, British Soldiers: Cultural Citizenship in the New Imperialism', Ethnicities, (13)1, 110-26.

Rogers, P., 2017. Irregular War: The New Threat from the Margins. London: I.B.Tauris. Sengupta, K., 2016. 'The British Army launches drive to recruit more Muslims'. The Independent. 5 February. http://www.independent.co.uk/news/uk/home-news/the-britisharmy-launches-drive-to-recruit-more-muslims-10027300.html (accessed 27.07.17)

Siblon, J., 2008. "'Monument Mania?" Public space and the black and Asian presence in the London landscape', in Ashton, P. \& Kean H. Public History and Heritage Today: People and their pasts. Basingstoke: Palgrave Macmillan, 146-162.

Ware, V., 2010. 'Whiteness in the Glare of War: Soldiers, Migrants and Citizenship'. Ethnicities, 10(3), 313-30.

Ware, V., 2012/2014. Military Migrants: Fighting for YOUR Country. Basingstoke: Palgrave Macmillan. 
Ware, V., 2013. 'Can you Have Muslim Soldiers? Diversity as a Martial Value'. In Nisha

Kapoor, N., Kalra, V., Rhodes, J., eds. The State of Race. Basingstoke: Palgrave Macmillan. 121-164.

Warsi, S., 2013. The First World War: the Commonwealth Contribution.

https://www.gov.uk/government/speeches/the-first-world-war-the-commonwealthcontribution (accessed 01.05.17).

\footnotetext{
${ }^{1}$ https://www.gov.uk/government/news/stephen-williams-launches-restorationprogramme-of-first-world-war-muslim-burial-ground

${ }^{2}$ https://historicengland.org.uk/whats-new/news/future-golden-for-muslim-burial-ground/

${ }^{3}$ http://www.wokingnet.co.uk/news/prayer-service-marks-commencement-of-peace-
} garden-works-at-muslim-burial-ground/

${ }^{4}$ https://historicengland.org.uk/whats-new/news/future-golden-for-muslim-burial-ground/ ${ }^{5}$ http://www.wokingnewsandmail.co.uk/?p=10357

${ }^{6}$ http://www.bbc.co.uk/news/uk-england-surrey-35209441

${ }^{7}$ See also: 'What is institutional racism?' Guardian, Wednesday 24 February, 1999. http://goo.gl/0nJbW (accessed 27.07.17).

${ }^{8}$ The October 2012 Diversity Dashboard report (p.1) showed, for example, that:

- The overall female representation of the UK Regular Forces was 9.7 per cent, this has remained constant between 1 October 2011 and 1 October 2012.

- BME personnel comprised 7.1 per cent of the UK Regular Forces, continuing a long term gradual increase in the proportion of BME personnel. This differs considerably by officer 
( 2.4 per cent) and other ranks ( 8.0 per cent). There are also notable variations by Service with the Army employing the most BME personnel (10.1 per cent) and the RAF the least (2.0 per cent). Ministry of Defence October 2012.

${ }^{9}$ The rapid increase in numbers of 'military migrants' soon proved its PR value in the face of British National Party claims that military service in defence of the UK was an all-white affair (Ware 2010). However, the arrest in 2017 of five servicemen allegedly discovered to be members of the banned neo-Nazi organization National Action indicated that current and former soldiers could be particularly vulnerable to the allure of white supremacist groups (Davey 2017).

${ }^{10}$ For more evidence of the shortfall in recruitment, see, for example: http://www.parliament.uk/business/publications/written-questions-answersstatements/written-question/Commons/2017-01-17/60327/

${ }^{11}$ Choudary played a key role in the group, Al-Muhajiroun, which was banned under terrorism legislation, as well as successor groups such as Islam4UK and Muslims Against Crusades. He received a five and a half year sentence in September 2016 after being convicted of urging Muslims to support Isis in a series of talks posted on YouTube.

${ }^{12}$ The Ahmadiyya Movement was founded in India in 1889 by Hazrat Mirza Ghulam Ahmad to promote Islam as a universal religion of peace. Established in the UK since 1913, the Movement built London's first mosque in 1926 (The London Mosque in Putney). There are now one hundred branches across Britain and a number of mosques have been opened including the landmark Baitul Futuh mosque in south London, which is the largest in western Europe. See http://www.loveforallhatredfornone.org for more details. 
The Ahmadiyya community is not recognised by the Muslim Council of Britain due to theological differences. See http://www.mcb.org.uk/position-statement-the-muslimcouncil-of-britain-and-ahmadis/ (6 April 2016) for more detail. 